\title{
Siropins, novel serine protease inhibitors from gut microbiota acting on human proteases involved in inflammatory bowel diseases
}

\author{
Héla Mkaouar 1,2, Nizar Akermi 1,2, Vincent Mariaule3, Samira Boudebbouze', Nadia Gaci', Florette Szukala1, \\ Nicolas Pons ${ }^{4}$, Josan Marquez ${ }^{3}$, Ali Gargouri², Emmanuelle Maguin ${ }^{1}$ and Moez Rhimi ${ }^{{ }^{*}}$
}

\begin{abstract}
Background: In eukaryotes, the serpins constitute a wide family of protease inhibitors regulating many physiological pathways. Many reports stressed the key role of serpins in several human physiopathologies including mainly the inflammatory bowel diseases. In this context, eukaryotic serpins were largely studied and their use to limit inflammation was reported. In comparison to that, bacterial serpins and mainly those from human gut microbiota remain poorly studied.
\end{abstract}

Results: The two genes encoding for putative serpins from the human gut bacterium Eubacterium sireaum, display low sequence identities. These genes were overexpressed and the encoded proteins, named Siropins, were purified. Activity studies demonstrated that both purified proteins inhibited serine proteases but surprisingly they preferentially inhibited two human serine proteases (Human Neutrophil Elastase and Proteinase3). The biochemical characterization of these Siropins revealed that Siropin 1 was the most active and stable at low pH values while Siropin 2 was more thermoactive and thermostable. Kinetic analysis allowed the determination of the stoichiometry of inhibition (SI) which was around 1 and of the association rate constants of $7.7 \times 10^{4}$ for the Human Neutrophil Elastase and $2.6 \times 10^{5}$ for the Proteinase3. Moreover, both Siropins displayed the ability to inhibit proteases usually present in fecal waters. Altogether our data indicate the high efficiency of Siropins and their probable involvement in the control of the overall intestine protease activity.

Conclusions: Here we report the purification and the biochemical characterization of two novel serpins originated from Eubacterium sireaum, a human gastro-intestinal tract commensal bacteria. These proteins that we called Siropins, efficiently inhibited two human proteases reported to be associated with inflammatory bowel diseases. The determination of the biochemical properties of these enzymes revealed different temperature and $\mathrm{pH}$ behaviours that may reflect adaptation of this human commensal bacterium to different ecological environments. To the best of our knowledge, it is the first bacterial serpins showing an attractive inhibition of fecal proteases recovered from a mice group with chemically induced inflammation. Altogether our data highlight the interesting potential of Siropins, and serpins from the human gut microbiota in general, to be used as new alternative to face inflammatory diseases.

Keywords: Commensal bacteria, Serpin, Fecal protease, Biochemical studies

\section{Background}

The serine protease inhibitors (serpins) represent the most widely distributed superfamily of protease

\footnotetext{
*Correspondence: moez.rhimi@jouy.inra.fr

1 UMR 1319 Micalis, INRA, AgroParisTech, Université Paris-Saclay,

78350 Jouy-en-Josas, France

Full list of author information is available at the end of the article
}

inhibitors having been identified across all branches of life including eukaryotes as well as viruses and prokaryotes [1, 2]. Serpins are being extensively studied in humans and they have been reported to inhibit proteolytic activities involved in many physiological processes including: inflammatory responses, blood coagulation and fibrinolysis $[3,4]$. The viral serpins are associated to 
virulence through the inactivation of the proteases of the host immune system [5, 6]. Moreover, serpins also operate through non inhibitory mechanisms on many physiological functions such as tumor suppression, molecular chaperone activity, chromatin compaction and hormone transport [1]. Unlike small protease inhibitors acting by a reversible way, serpins are distinguishable by their irreversible suicide mechanism of inhibition [7]. Indeed, the serpin inhibition activity is associated to the Reactive Center Loop (RCL) which interacts with target protease thereby resulting in the cleavage of the RCL that enables the establishment of a covalent acyl-enzyme complex. These main structural reshuffles will induce an important distortion of the protease leading to its inactivation [8].

Comparatively to the knowledge on the eukaryotic serpins function, that regarding the bacterial serpins is still very limited [1]. In fact, until now only few microbial serpins were reported including those from Clostridium thermocellum, Tannerella forsythia, Thermobifida fusca and Thermoanaerobacter tengcondensis [9-13]. While these bacterial serpins were characterized, their physiological roles are still to be investigated.

Interestingly, only one serpin from the human commensal bacterium Bifidobacterium longum NCC2705 strain was studied. In fact, it was demonstrated that this bacterial serpin inhibited several eukaryotic serine proteases and mainly the Human Neutrophil Elastase (HNE) [14]. Taking into account that eukaryotic serine proteases are associated with several human protease-mediated physiopathologies and essentially inflammatory bowel diseases (IBD), the serpins can constitute a promising therapeutic approach to treat such diseases [14]. This claim is strengthened by the demonstration that the human specific inhibitor of HNE (Elafin) allowed the reduction of induced digestive inflammation in a rodent model [15]. In this framework, the interest towards the bacterial serpins from the human gut microbiota is taking more importance when one considers the higher numbers of these polypeptides compared to the 36 serpins encoded by the human body [1]. The recent scientific breakthroughs in the gut microbiota studies clearly demonstrated the association between the gut microbiota and IBD $[16,17]$. Consequently, the serpins encoded by the human gut microbiota today appear as attractive candidates to counteract the deleterious damages associated with the GIT-derived protease activities and may ensure an important competitive advantage to survive in this ecological context $[14,18]$. Therefore, serpins from the gut microbiota may have therapeutic potential which remains hitherto unexplored.

Here we report the cloning, over-expression, purification and biochemical characterization of two novel serpins isolated from the human commensal Eubacterium sireaum. The purified serpins were characterized. They display differential inhibitor efficiency against human serine proteases. Interestingly, these proteins constitute the first bacterial serpins inhibiting the human Proteinase 3 and the fecal proteases from inflamed mice.

\section{Results and discussion}

\section{Genes in silico analysis, cloning and over-expression}

Analysis of the amino-acid sequence multiple alignment demonstrates that Siropin 1 and 2 have $60 \%$ of identity. Sequence inspection of the Siropin 1 and 2 with other serpins reveals that they display sequence identities of only 19 and $20 \%$ with the previously studied serpin from the gut bacterium B. longum (Fig. 1). The same study revealed that the serpins from Tannerella forsythia and Thermobifida fusca displayed low identities of 23 and 24\% with the Siropin 1 and of 21 and 19\% with Siropin 2. By using TMHMM and SignalP programs we conclude that Siropin 1 is an intracellular protein; but Siropin 2 was significantly predicted as an extracellular protein (data not shown). The sequence identity of the two Siropins increased to $63 \%$ when the presumed signal sequence was omitted from Siropin 2. In addition, the alignment of the RCL sequences from Siropins displays an identity value of only $48 \%$. These low sequence identities can be explained by what was previously suggested concerning the serpin genes in prokaryotes i.e., that they are most probably prone to horizontal gene transfer $[2,19]$.

As shown in Fig. 1, both Siropins possess three $\beta$ sheets, eight $\alpha$ helices and an exposed RCL which are the structural elements that characterize all members of serpin family $[2,20]$. Moreover, analysis of the RCL region demonstrates that the Siropins hinge sequences are mainly composed by small and highly conserved amino acids including Glycine and Alanine (Fig. 1). This observation suggests that the two proteins studied herein most probably act as proteases inhibitors [2, 21].

To investigate this hypothesis, two DNA fragments of approximately $1.5 \mathrm{~kb}$ were amplified using Eubacterium siraeum chromosomal DNA as template and two oligonucleotides designed for each gene. These DNA fragments were cloned under control of the $\mathrm{T} 7$ promoter and in frame with six histidine residues at the $\mathrm{N}$-terminal side of the encoded proteins. For both Siropins, structural model showed that the $\mathrm{N}$-termini are located away from the active sites (Additional file 1: Fig. S1). The calculated molecular weights were 43.75 and $48.1 \mathrm{kDa}$ for Siropin 1 and Siropin 2, respectively. After transformation into E. coli BL21 (DE3), numerous colonies were observed and subsequently analyzed by PCR and DNA sequencing. Monitoring of the liquid culture of each selected clone followed by western blotting using the intracellular crude extract, showed the presence of bands with a molecular 
B. longurm
T. fusca

T. forsythia

T.tengcongensi

Siropin_1

Siropin

Alpha-1-antitrypsin

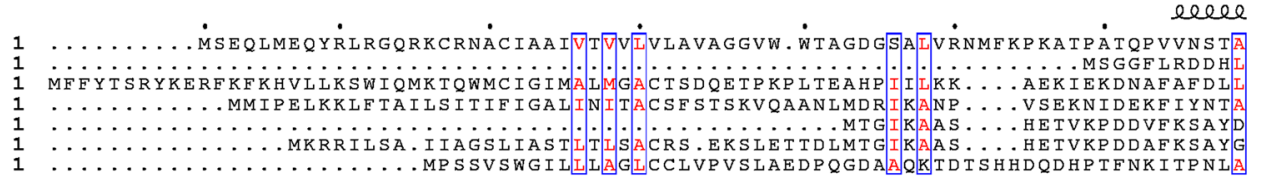

(1)

$\mathrm{hA}$

$\mathrm{hB}$

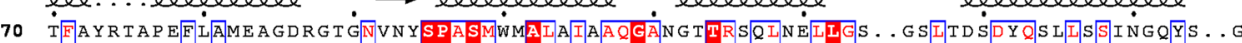

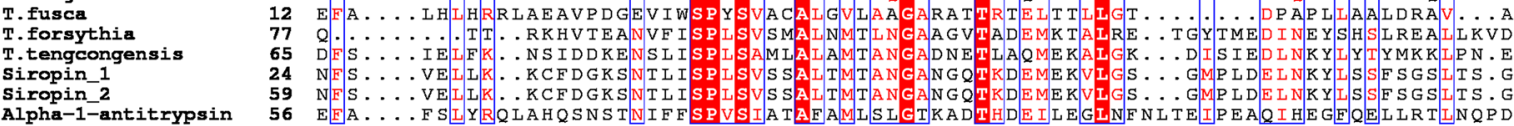

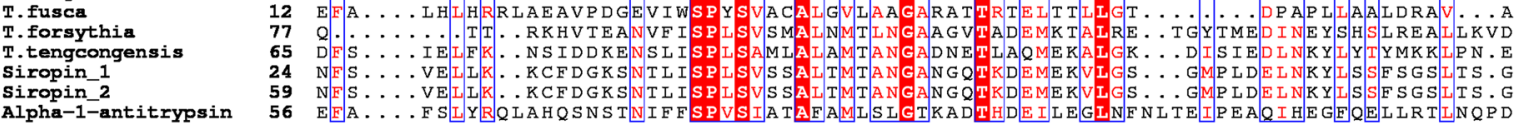

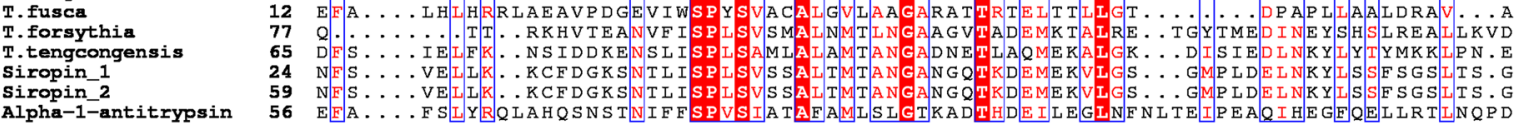

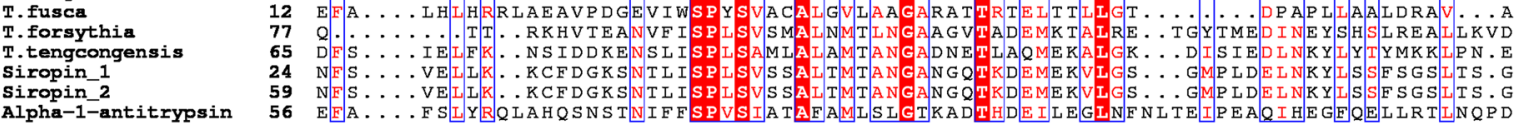

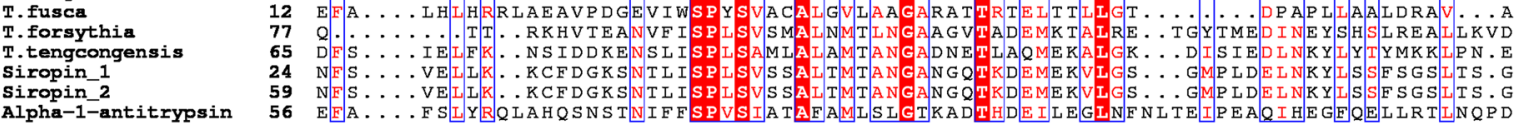
Alpha-1-antitrypsin

B. longurn T. fusca T.tengcongensis Siropin_1 Siropin_1 Alpha-1-antitrypsin
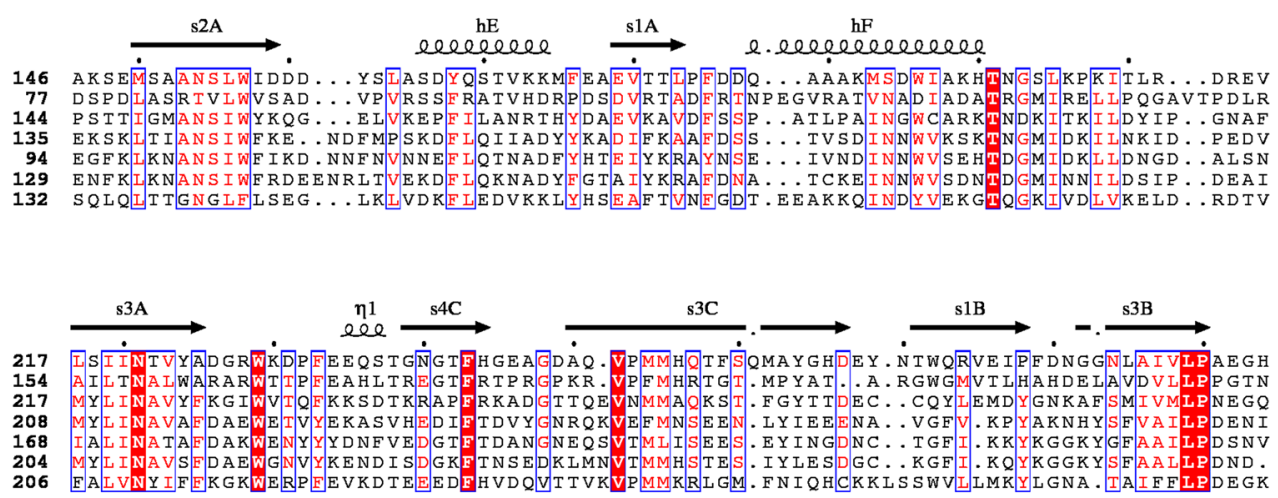

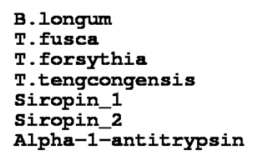

Alpha-1-antitrypsin

\section{B. longum T. fusca T. forsythia Siropin_1 Siropin_1 Siropin_2}
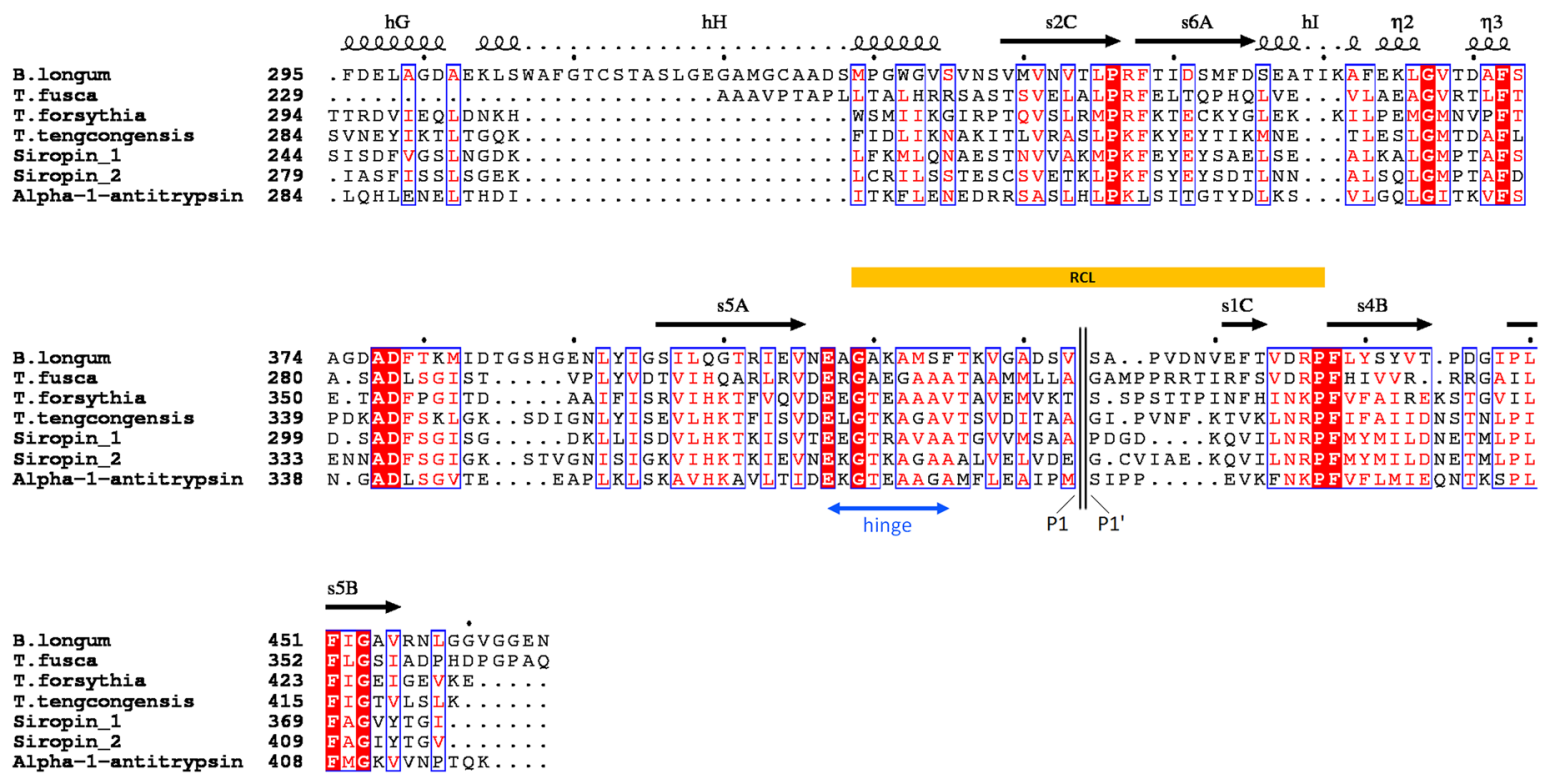

Fig. 1 Multiple sequence alignment of Siropin 1 and 2 with Thermopin (Uniprot accession number Q47NK3R), Miropin (Uniprot accession number G8UQY8), human a-1-antitrypsin (UniProt accession number P01009), B. longum serpin (UniProt accession number Q8G7X7) and Tengpin (UniProt accession number Q8R9P5). The structural elements shown above the alignment were generated using the native $a-1$-antitrypsin structure (PDB ID: 1QLP) sequence invariant residues between sequences are typed red on a white background and residues conserved within each group are displayed as white letters on a red background. Underlined sequences represent the predicted hinge region (blue) and reactive center loop (yellow). The predicted cleavage site is marked with a double vertical line. P1 and P1' residues are labeled 
weight of nearly 44 and $46 \mathrm{kDa}$ close to the theoretically expected one (Fig. 2b, d). These results were confirmed by mass spectrometry analysis which proved the correspondence of these protein species to Siropin 1 and 2 (data not shown). These data demonstrate the molecular cloning and the expression of the E. siraeum serpin genes in E. coli BL21.

\section{Purification of Siropins, spectrum and stoichiometry of inhibition}

After an overnight liquid cell cultures of the recombinant E. coli BL21 strains over-expressing both serpins, the protein crude extracts were subjected to an affinity chromatography step. High purity enzyme preparations were obtained with size exclusion chromatographies which displayed single elution peaks with apparent molecular masses of $45 \mathrm{kDa}$ and $50 \mathrm{kDa}$ for Siropin 1 and 2, respectively (Fig. 1e). The electrophoresis under reducing conditions and mass spectrometry analysis revealed the presence of homogenous single bands with molecular masses of around 44 and $46 \mathrm{kDa}$ (Fig. 2a, c, f and g), suggesting that both serpins from $E$. siraeum have a monomeric arrangement. Such organization is similar to those adopted by serpins from Thermococcus kodakaraensis, Tannerella forsythia, Pyrobaculum aerophilum and Thermobifida fusca [10, 12, 22, 23].

Interestingly, purification yields were about $12 \mathrm{mg}$ and $8 \mathrm{mg}$ of protein per liter of culture for Siropin 1 and 2, respectively. In comparison, previously reported purification yields per liter were $25 \mu \mathrm{g}, 3$ and $10 \mathrm{mg}$ for serpins from Tannerella forsythia, Thermococcus kodakaraensis and Bifidobacterium longum [10, 14, 22]. Altogether

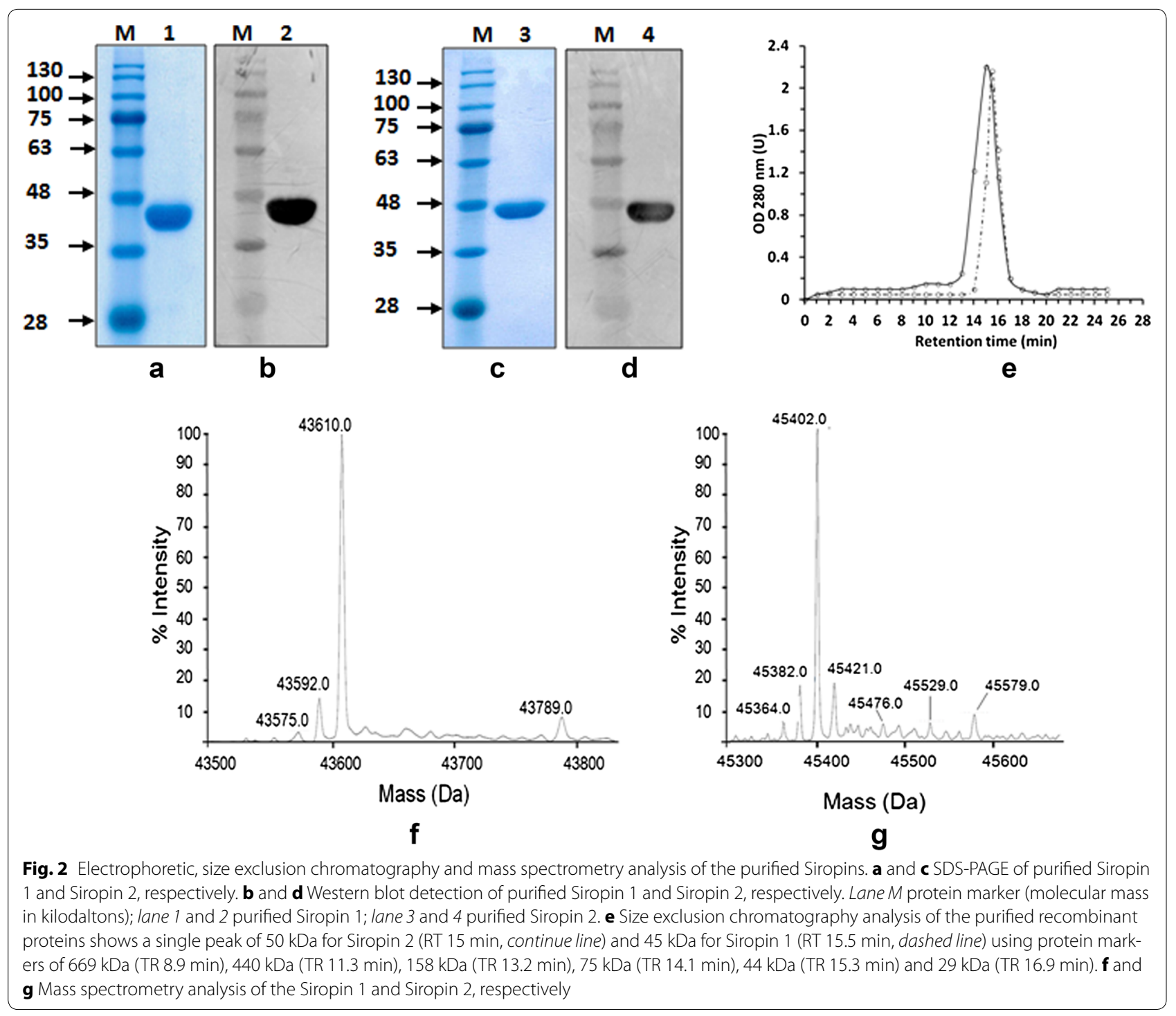


these data indicate that the Siropin 1 and 2 are well expressed in $E$. coli and that the used purification procedure allowed the achievement of high yields of serpins. The obtained pure protein amounts were sufficient for the investigation of the inhibition spectrum of Siropins. As shown in Fig. 3a, none of the Siropins inhibited the pancreatic porcine elastase (PPE), bovine pancreatic trypsin (BPT) and chymotrypsin (BPC). The same result
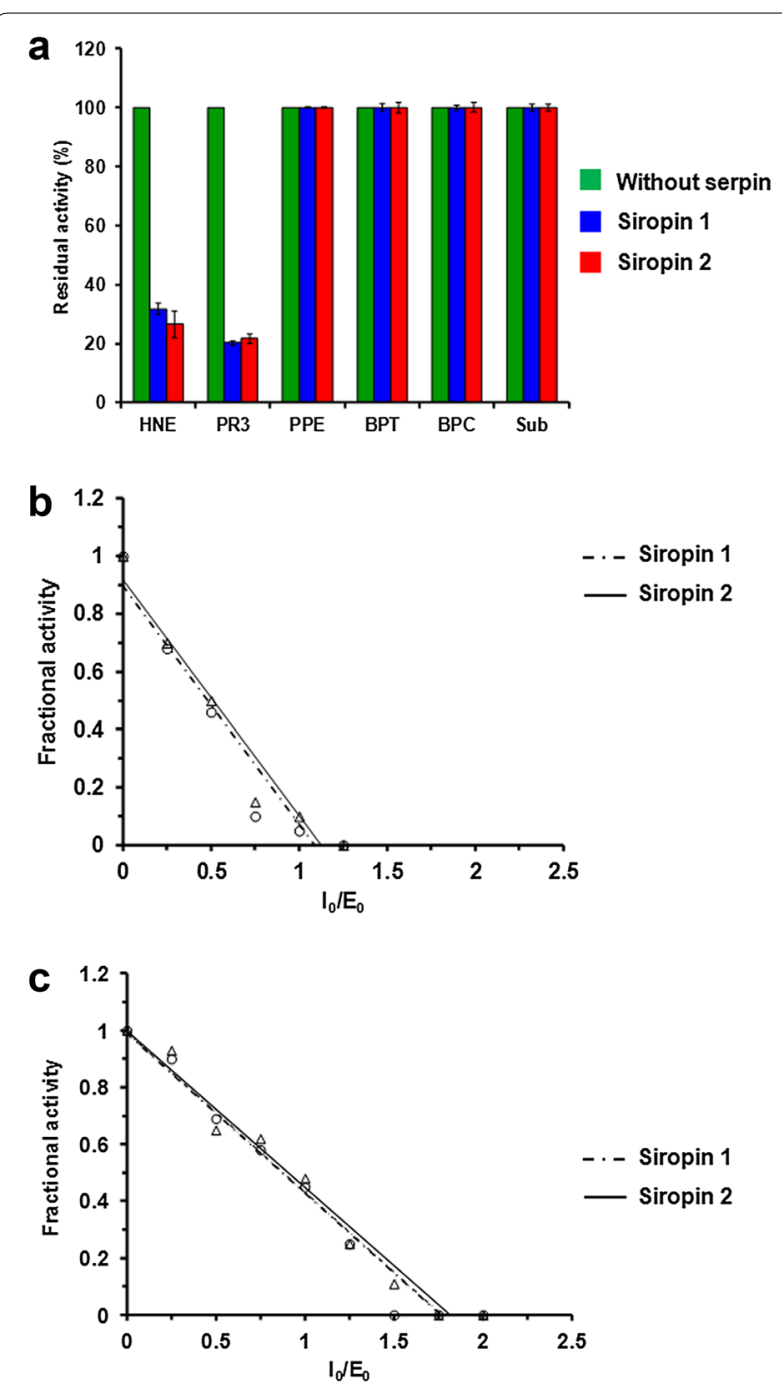

Fig. 3 Spectrum and stoichiometry of inhibition of purified Siropins. a Effect of Siropin 1 and 2 on HNE human neutropil elastase, PR3 proteinase 3, PPE porcine pancreatic elastase, BPT bovine pancreatic trypsine, $B P C$ bovine pancreatic chymotrypsine and Sub subtilisine.

The activity of each protease was assayed alone (green), pre-incubated with Siropin 1 (blue) or with siropin 2 (red). Measured protease activities without serpins were defined as 100\%. Error bars represent the standard deviation from three independent experiments. $\mathbf{b}$ and c Stoichiometry of inhibition of Siropins. Fractional protease activity of HNE (b) and PR3 (c) was plotted after incubation with various amounts of Siropin 1 (Dashed, ${ }^{-}{ }^{-}$) or Siropin 2 (Continuous, $-^{-}$) was also observed when using subtilisin (Sub), the bacterial serine protease from Bacillus subtilis. In contrast, Siropin 1 and 2 efficiently inhibited two human serine proteases: the Human Neutrophil elastase (HNE) and the Proteinase3 (PR3). It is noteworthy that with previously reported serine proteases even at 10 or 20 fold higher molar concentrations, no inhibition was observed.

In the case of HNE and PR3 the inhibition level was dependent upon Siropins concentration; it allowed us to determine the stoichiometry of inhibition (SI). Figure $3 \mathrm{~b}, \mathrm{c}$ revealed that Siropin 1 has SI values of 1.76 and 1.1 for HNE and PR3, respectively. Siropin 2 shows SIs of 1.82 for HNE and 1.1 for PR3 (Fig. 3b, c). SI values of Siropins with HNE are lower than that of serpin from Tannerella forsythia $(\mathrm{SI}=3.4)$ and similar to those of serpins from B. longum, T. tengcondensis and of the human $\alpha$-1-antitrypsin $[13,14,24]$. Concerning the PR3, the SIs of Siropins were similar to that of the human $\alpha-1$ antitrypsin [25]. Furthermore as far as we know, Siropins constitute the first bacterial serpins inhibiting the human PR3. It is well recognized that serpins allow the defense of bacteria through the inhibition of proteolytic activities contributing thus to their adaptation towards ecological environment. At least, it was reported that the serpins from Bacillus brevis and Bifidobacterium breve protected these bacteria from exogenous attacks through the inhibition of proteases $[18,26]$. In the case of E. sireaum, our data reavealed that it can use its Siropins to ensure a protection against the host proteases, HNE and PR3. Similar behavior was previously described in case of the ecotin from E. coli [27].

Above all it appeared that Siropins act efficiently against human proteases while they were not active against the $B$. subtilis subtilisin. This feature takes more importance when one considers that (i) HNE and PR3 are highly over-expressed in subjects suffering from inflammatory bowel diseases (IBD) when compared to healthy one $[15,28,29]$ and (ii) many reports stressed the involvement of serine proteases on human inflammatory physiopathology's and mainly HNE and PR3 [15, 28, 29].

\section{Identification of the RCL cleavage sites}

In order to determine the $\mathrm{P} 1-\mathrm{P} 1^{\prime}$ cleavage site in the RCL of Siropins, the purified proteins were incubated with target proteases and subsequently analyzed by SDSPAGE and mass spectrometry (Fig. 4). In the case of Siropins, the complex band was not detectable by SDSPAGE analysis. This kind of complex instability has been previously reported with other inhibitory serpins and it is assumed that it results from a nucleophile or water attack that can occur upon the complex formation leading to the release of cleaved serpin and distorted protease [30]. In both case (HNE and PR3) the intensity of the 


\section{a}

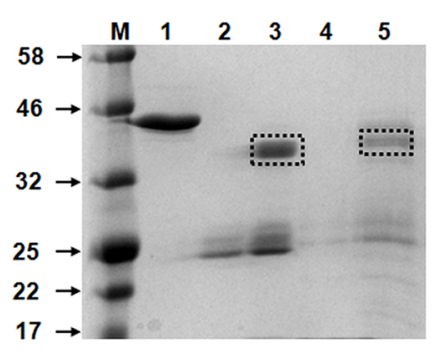

Siropin 2

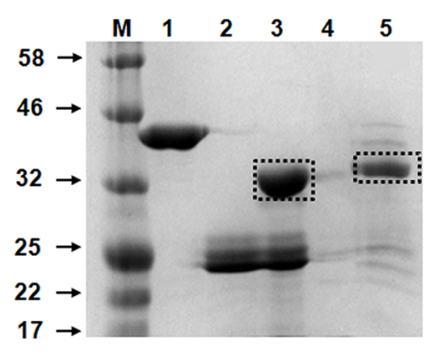

b

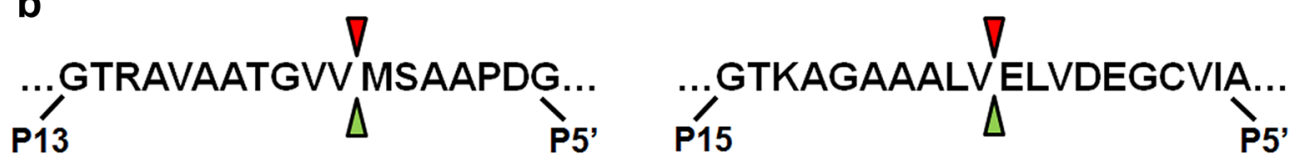

$\nabla$ Human Neutrophil Elastase

\section{$\triangle$ Proteinase3}

Fig. 4 Determination of the RCL cleavage sites of the Siropin 1 and 2 using mass spectrometry analysis. a The stained protein bands labelled with frames were excised and subjected to mass spectrometry analysis. Siropin 1: M protein marker; 1 Siropin 1; 2 HNE; 3 Siropin 1 + HNE; 4 PR3; 5 Siropin 1 + PR3. Siropin 2: M protein marker; 1 Siropin 2; 2 HNE; 3 Siropin $2+H N E ; 4$ PR3; 5 Siropin $2+$ PR3. b Diagram of the reactive center loops showing the cleavage sites for each Siropin identified with HNE and PR3

band corresponding to untreated serpin (44 for Siropin 1 and $46 \mathrm{kDa}$ for Siropin 2) decreased, while a slightly lower band appear upon addition of the target protease (Fig. 4a). Further mass spectrometry analyses were performed on the digestion band and obtained results revealed that this band correspond to the RCL-cleaved Siropins (data not shown). Subsequently, based on the sequence analysis of this cleaved form, we successfully determined the Siropins cleavage sites which correspond to P3-P2 (Val338-Met339) peptide bonds for Siropin 1 and P6-P5 (Val375-Glu376) bond for Siropin 2 both for HNE and PR3 (Fig. 4b). Interestingly, those cleavage sites are consistent with the specificity of HNE and PR3 for Val or Ala at P1 position.

\section{Effects of temperature and $\mathrm{pH}$ on Siropins activity and stability}

The analysis of the inhibition patterns at different temperatures demonstrated that Siropin 2 was fully active at temperatures until $50{ }^{\circ} \mathrm{C}$ (Fig. 5a). The same study established that Siropin 1 was fully active up to $40^{\circ} \mathrm{C}$ and displayed a relative inhibition of $88 \%$ at $50{ }^{\circ} \mathrm{C}$. Amazingly, at $60{ }^{\circ} \mathrm{C}$ Siropin 2 preserves more than $90 \%$ of its activity whereas Siropin 1 kept less than $10 \%$ of its activity. At temperatures above $60{ }^{\circ} \mathrm{C}$, Siropin 2 retained $30-35 \%$ of its initial activity but Siropin 1 was almost inactive (Fig. 5a). Therefore, we conclude that both Siropins are highly active at low temperatures, while at high temperatures the Siropin 2 is more thermoactive than Siropin 1. In comparison the previously described bacterial serpin from a marine uncultured microorganism and Thermococcus kodakaraensis displayed optimal inhibitions of 25 and $100{ }^{\circ} \mathrm{C}$, respectively [22, 31].

Study of $\mathrm{pH}$ effect on Siropins revealed that these proteins were highly active at $\mathrm{pH} 7.0$ (Fig. 5b). Moreover, they retained more than $75 \%$ of their activities from $\mathrm{pH}$ 6.0 to 10 . Remarkably, Siropin 1 displayed higher relative activities at $\mathrm{pH}$ values ranged between 2.0 and 5.0. For example at $\mathrm{pH}$ 3.0, the relative activities of Siropin 1 and Siropin 2 were 60 and 10\% respectively. Under high pH values, Siropin 1 also kept a higher relative activity than Siropin 2 e.g., at $\mathrm{pH} 10$ Siropin 1 and 2 preserved 97 and $80 \%$ of their relative activities, respectively.

Previous studies of the serpin deriving from a marine uncultured microorganism showed an optimal $\mathrm{pH}$ range of 7.0 to 8.0 and an optimal $\mathrm{pH}$ of 7.0 for the serpin isolated from Haemonchus contortus [31, 32].

Our results established that Siropin 2 is distinguishable from Siropin 1 by its tolerance to high temperatures while Siropin 1 was active at extreme $\mathrm{pH}$ values compared to Siropin 2. In the other hand, both Siropins are highly active at wide range of temperature $\left(4.0-50{ }^{\circ} \mathrm{C}\right)$ and $\mathrm{pH}$ (6.0-10) indicating a certain versatility of these proteins compatible with the gastrointestinal environment.

The thermostability studies showed that Siropin 1 was fully stable at temperatures until $55^{\circ} \mathrm{C}$ whereas at 


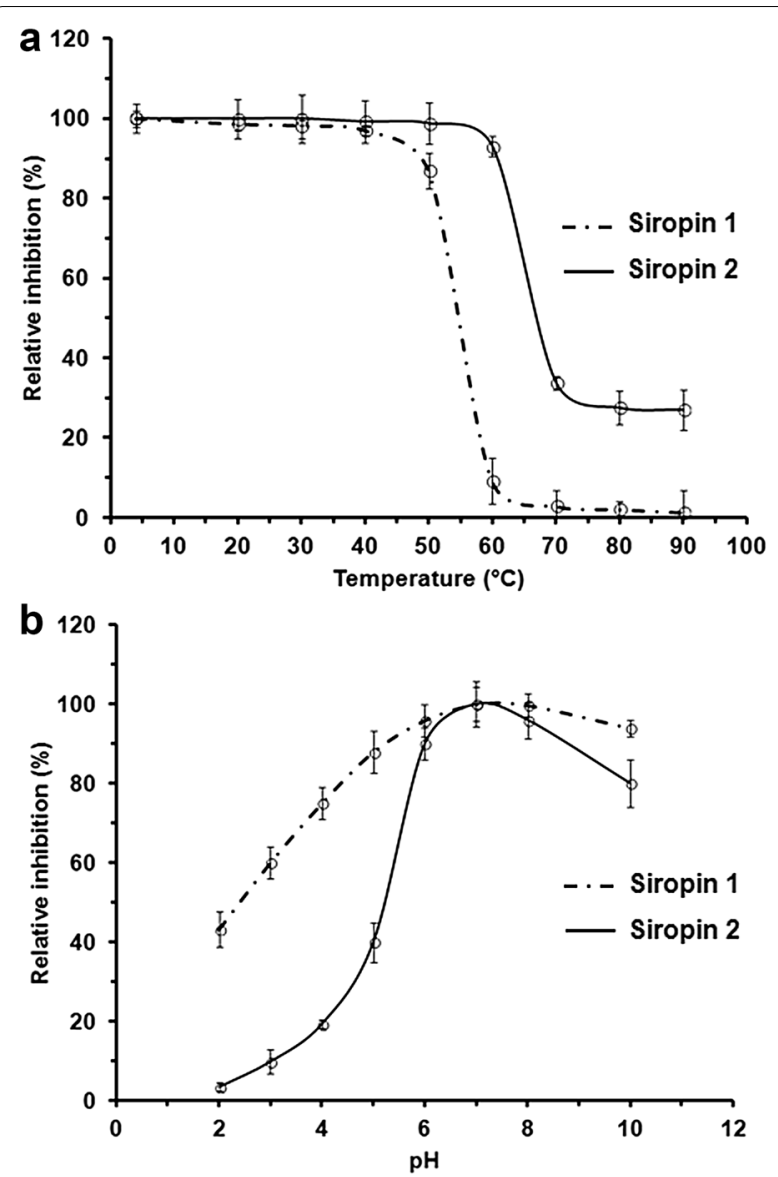

Fig. 5 Effect of temperature (a) and $\mathrm{pH}(\mathbf{b})$ on the inhibitory effect of the purified Siropin 1 (dashed line) and Siropin 2 (continuous line). Inhibitions at the optimal $\mathrm{pH}$ and the optimal temperature were defined as 100\%. Error bars represent the standard deviation from three independent experiments

above temperatures its thermostability dropped rapidly: at $60{ }^{\circ} \mathrm{C}$ the enzyme's half-life time was $10 \pm 1 \mathrm{~min}$. By contrast, Siropin 2 was fully stable upto $60{ }^{\circ} \mathrm{C}$, and at $70{ }^{\circ} \mathrm{C}$, its half-live was $21 \pm 0.5 \mathrm{~min}$ while it was only $3 \pm 0.5 \mathrm{~min}$ for Siropin 1 (Table 1). At higher temperatures including 80 and $90{ }^{\circ} \mathrm{C}$ the Siropin 1 was inactive but the Siropin 2 still displayed half-lives of $20 \pm 2.0 \mathrm{~min}$ and $19 \pm 0.5 \mathrm{~min}$, respectively (Table 1 ). These results highlighted again not only the stronger thermoactivity but also the higher thermostability of Siropin 2 compared to Siropin 1. In previous reports, the serpins from the thermophilic Clostridium thermocellum and Thermobifida fusca displayed half-lives of $30 \mathrm{~min}$ at $70{ }^{\circ} \mathrm{C}$ and $28 \mathrm{~min}$ at $60{ }^{\circ} \mathrm{C}$, respectively $[9,12]$.

Study of the $\mathrm{pH}$ stability revealed that both Siropins were highly stable at $\mathrm{pH} 7.0$ and 8.0 during 8 h. At $\mathrm{pH}$ 6.0 the Siropin 1 was completely stable after 8 h; yet Siropin 2 displays half-live of $2.6 \mathrm{~h}$. The same behavior was
Table 1 Study of the thermal stability of Siropins

\begin{tabular}{lllll}
\hline & $\mathbf{6 0}{ }^{\circ} \mathbf{C}$ & $\begin{array}{l}\mathbf{7 0}{ }^{\circ} \mathbf{C} \\
\text { Half-lives }\end{array}$ & $\begin{array}{l}\mathbf{8 0}{ }^{\circ} \mathbf{C} \\
\left(\mathbf{t}_{\mathbf{1} / \mathbf{2}}, \mathbf{m i n}\right)\end{array}$ & $\mathbf{9 0}{ }^{\circ} \mathbf{C}$ \\
\hline Siropin 1 & $10 \pm 1.0$ & $3.0 \pm 0.5$ & ND & ND \\
Siropin 2 & $>120$ & $21 \pm 1.5$ & $20 \pm 2.0$ & $19 \pm 0.5$ \\
\hline
\end{tabular}

Results are the mean and standard deviation from three independent experiments

ND not detected

observed at higher $\mathrm{pH}$ values thus underlying the better pH stability of Siropin 1 compared to Siropin 2 (Table 2).

These different thermal and $\mathrm{pH}$ stability behaviors of Siropin 1 and 2 can be related to their low amino-acid sequence identity (63\%). Studies on structure-function relationships of these bacterial serpin, mainly through the determination of the 3D structure of these proteins, will provide further structural explanations.

The different Siropins behaviors in terms of $\mathrm{pH}$ and temperature activities and stabilities can be related to the adaptation of this commensal bacterium E. siraeum to different ecological niches such as the stomach (acid $\mathrm{pH}$ ) and the bowels (neutral $\mathrm{pH}$ ).

\section{Kinetic studies}

As previously reported serpins inhibit proteases through an irreversible mechanism, therefore the main kinetic parameter which characterizes their inhibition efficiencies is the association rate constant $\left(\mathrm{k}_{\mathrm{a}}\right)$. For both target proteases studied herein the second-order association rate constants were calculated by progress curve analysis (Fig. 6). Using the Siropin 1 , the $k_{\mathrm{a}}$ values were $8.4 \pm 0.07 \times 10^{4} \mathrm{M}^{-1} \mathrm{~s}^{-1}$ and $2.6 \pm 0.02 \times 10^{5} \mathrm{M}^{-1} \mathrm{~s}^{-1}$ for HNE and PR3, respectively. In case of Siropin 2 we obtained $\mathrm{k}_{\mathrm{a}}$ of $7.7 \pm 0.02 \times 10^{4} \mathrm{M}^{-1} \mathrm{~s}^{-1}$ for HNE and of $1.1 \pm 0.04 \times 10^{5} \mathrm{M}^{-1} \mathrm{~s}^{-1}$ for PR3. These data prove that Siropins are more efficient with PR3 than with HNE. The analysis of $k_{a}$ values of previously reported serpins towards HNE shows that serpins from bacterial origin displayed comparable values to those of Siropins (Table 3). In comparison, the eukaryotic $\alpha$-1-antitrypsin and Elafin were more efficient with $\mathrm{k}_{\mathrm{a}}$ values of $6.510^{7}$ and $3.7 \times 10^{6} \mathrm{M}^{-1} \mathrm{~s}^{-1}$, respectively (Table 3 ). This higher efficiency can be explained by the fact that both $\alpha-1$ antitrypsin and Elafin are the natural human inhibitor of HNE. Such statement is reinforced with the observation that the $\alpha$-1-antitrypsin and Elafin also inhibited better the human serine protease PR3 than Siropin 1 and 2. However, we report for the first time the fact that bacterial serpins can inhibit the human PR3. Previous studies showed that to ensure the control of target proteases in blood plasma, serpins with less than $100 \mathrm{~ms}$ inhibition life-time are required [35]. Taken together our findings, it 
Table 2 Study of the thermal pH stability of Siropins

\begin{tabular}{lllllll}
\hline & $\mathbf{5}$ & $\mathbf{6}$ & $\mathbf{7}$ & $\mathbf{8}$ & $\mathbf{9}$ & $\mathbf{1 0}$ \\
& & & Half-lives & $\left.\mathbf{( t}_{\mathbf{1 / 2}}, \mathbf{m i n}\right)$ & $>415 \pm 3.0$ \\
Siropin 1 & $210 \pm 5.0$ & $>480$ & $>480$ & $>480$ & $>480$ & $230 \pm 3.0$ \\
Siropin 2 & $18 \pm 2.0$ & $160 \pm 1.0$ & $>480$ & $>480$ & $114 \pm 2.0$ \\
\hline
\end{tabular}

Results are the mean and standard deviation from three independent experiments
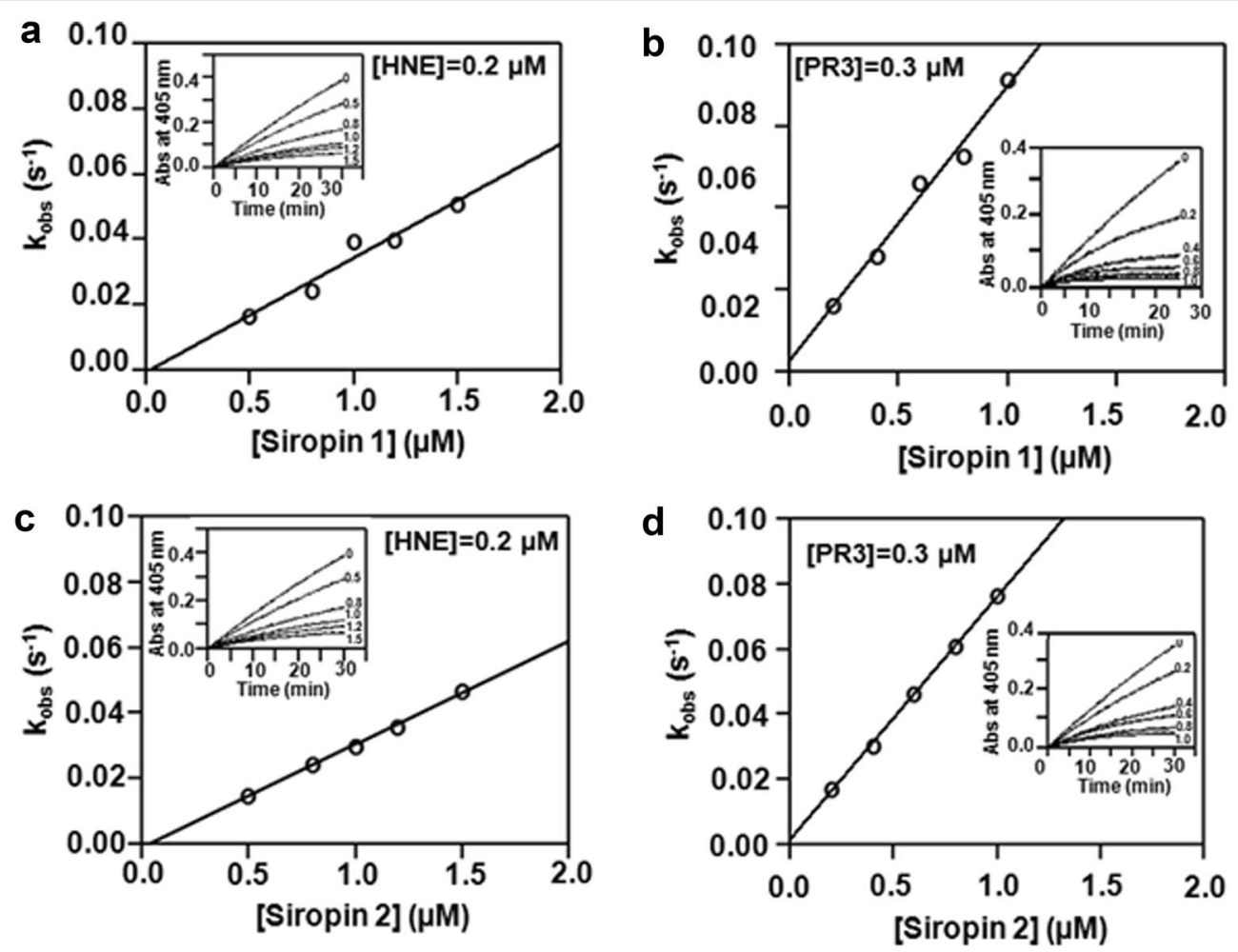

Fig. 6 Progress curves for proteases inhibition by Siropins. a and $\mathbf{c}$ HNE inhibition by Siropin 1 (a) and Siropin 2 (c). b and $\mathbf{d}$ PR3 inhibition by Siropin 1 (b) and Siropin 2 (d). Constant concentrations of HNE or PR3 were used with various amount of Siropin, the change in the absorbance was then performed at $37^{\circ} \mathrm{C}$. Used concentration of Siropin $(\mu \mathrm{M})$ are shown beside each progress curve. Obtained $k_{\text {obs }}$ rate were plotted against the Siropin concentration. The apparent second-order association constant $k_{\text {app }}^{\prime}$ was calculated as the slope of the fitted linear curve and then corrected to determine the second-order association constant $k_{a}$

can be assumed that Siropins could perform an effective protease inhibition in the gastro-intestinal tract.

\section{Siropins inhibit mice fecal proteases}

To check the ability of Siropins to inhibit proteases associated with intestinal inflammation, feces were recovered from two conventional mice groups: the first group was treated with PBS while in the second group inflammation was induced with Dextran sulfate sodium (DSS, 3\%). The measure of the total fecal protease activity (FPA) demonstrated that FPA in DSS-treated mice group was nearly 2.2 fold higher than that of the PBStreated group (Fig. 7a). Such results are in accordance with those reported in case of the human IBD patients
Table 3 Association rate constant values of previously reported serpins

\begin{tabular}{llll}
\hline & HNE & PR3 & Reference \\
\hline Siropin 1 & $8.4 \pm 0.07 \times 10^{4}$ & $2.6 \pm 0.02 \times 10^{5}$ & This study \\
Siropin 2 & $7.7 \pm 0.02 \times 10^{4}$ & $1.1 \pm 0.04 \times 10^{5}$ & This study \\
a-anti-trypsin & $6.5 \pm 4.0 \times 10^{7}$ & $1.0 \pm 0.2 \times 10^{6}$ & {$[25,33]$} \\
Elafin & $3.7 \pm 0.1 \times 10^{6}$ & $3.3 \pm 0.03 \times 10^{6}$ & {$[34]$} \\
Tengpin & $1.3 \times 10^{5}$ & $\mathrm{NR}$ & {$[13]$} \\
Miropin & $1.2 \pm 0.05 \times 10^{5}$ & $\mathrm{NR}$ & {$[10]$} \\
Serpin from B. longum & $4.7 \times 10^{4}$ & $\mathrm{NR}$ & {$[14]$} \\
\hline
\end{tabular}

NR not reported

Results are the mean and standard deviation from three independent experiments 


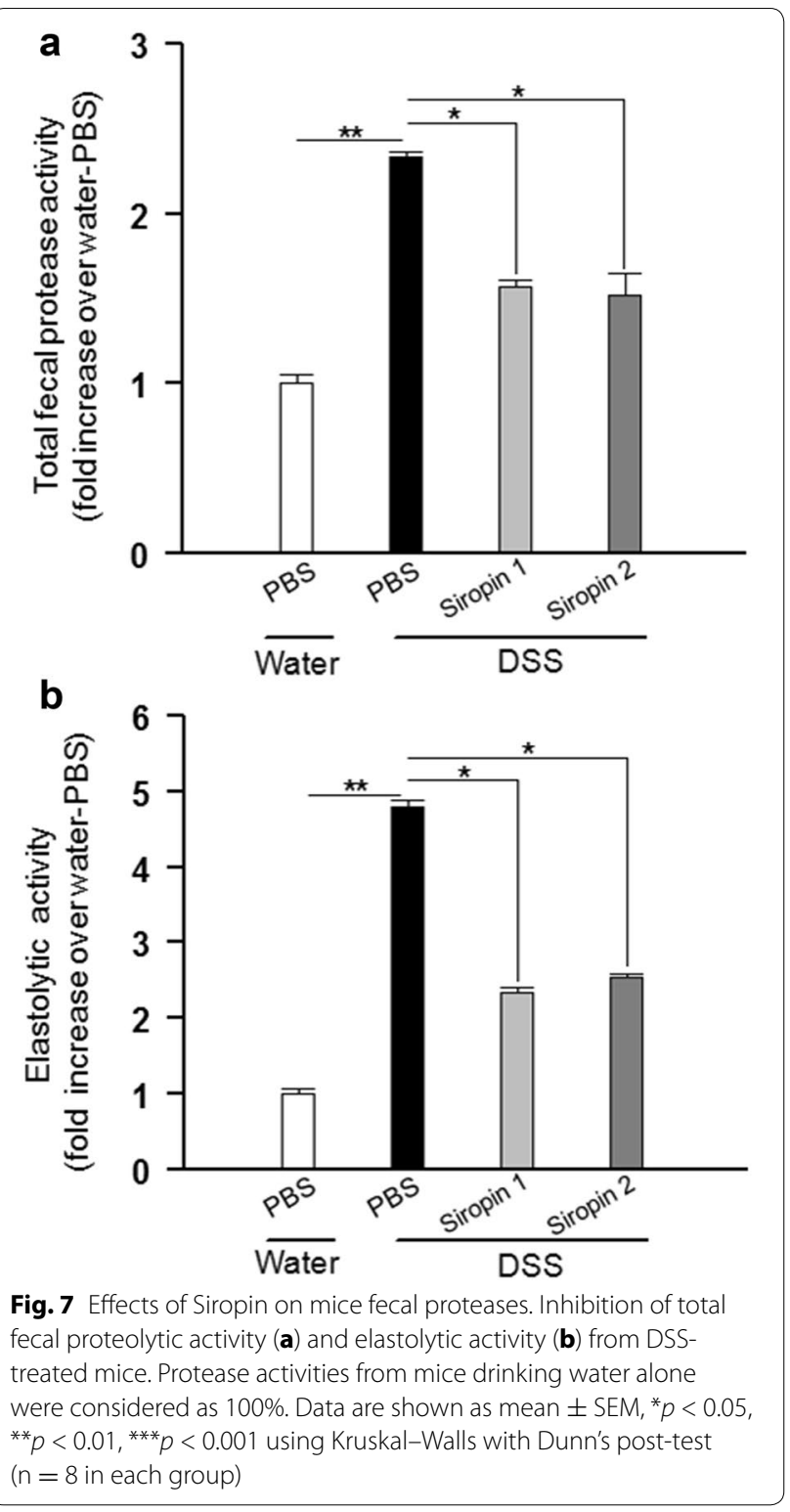

who displayed an increase of the FPA compared to that of healthy subjects [36, 37]. Hence our results confirmed again the involvement of proteases on the inflammatory bowel diseases. Several reports underlined the key role of elastolytic activity in inflammatory bowel diseases [15, $28,29]$. As shown in Fig. 7b, the level of measured elastolytic activity in mice treated with DSS was nearly fivefold higher than that of the PBS-treated mice group proving that the DSS treatment induced an increase of the protease level, and notably the elastolytic activity.

The analysis of the FPA in the presence of Siropins showed a significant decrease of the total proteolytic activity which was evaluated to 30 and $35 \%$ with Siropin 1 and 2, respectively (Fig. 7a). Interestingly when the Siropins were added, the elastolytic activity was reduced to $50 \%$ with Siropin 1 and to $46 \%$ with Siropin 2 . Altogether these data establish that the addition of Siropins allowed the decrease of the FPA activity in fecal water of DSS-inflamed mice with a pronounced effect on the elastolytic activities indicating that Siropins are highly active in such conditions.

These data highlighted the efficiency of the Siropins to inhibit fecal water proteases and thus their potential as good candidates to inhibit proteases associated with inflammation. Henceforth Siropins can constitute a promising therapeutic strategy to treat inflammatory diseases.

\section{Conclusions}

The human gut bacterium E. sireaum encoded two putative serpins which display low sequence identity together and with other bacterial serpins. Activity studies of these putative serpins demonstrated that they act as a serine protease inhibitors. The analysis of these novel bacterial serpins, called Siropins, revealed that they efficiently inhibit the human serine proteases HNE and PR3. Interestingly, Siropins are the first bacterial serpins that significantly inhibit the human PR3. The biochemical characterization of both Siropins indicated that Siropin 1 was the most active and stable at low $\mathrm{pH}$ values while Siropin 2 was more thermoactive and thermostable. These different behaviors can be associated to the adaptation of the commensal bacterium to different ecological niches. Kinetic studies demonstrated that Siropins were highly efficient in comparison to other bacterial serpins including that of $B$. longum conferring thus to Siropins an interesting potential to inhibit serine proteases and specifically those associated to several human physiopathologies. To assess this hypothesis we tested the impact of Siropins on the proteases fecal activities. This study evidenced that Siropins strongly inhibit the fecal proteases and mainly the elastolytic activities. Altogether, these results highlight the high potential of Siropins, and serpin from the human gut microbiota, as a powerful therapeutic strategy to treat protease-mediated pathologies and mainly inflammatory bowel diseases.

\section{Methods}

\section{Enzymes, reagents and substrates}

Used human proteases: Human Neutrophil Elastase (HNE) and Human Proteinase 3 (PR3) were purchased from elastin products company (EPC, Inc). Porcine pancreatic elastase (PPE), bovine pancreatic trypsine (BPT), bovine pancreatic chymotrypsine (BPC) and subtilisin Carlsberg (Sub) were obtained from Sigma. All substrates: Meosuc AAPV-pNA (Sigma) and MCA-RPKPVE-Nval-WRK(Dnp)- $\mathrm{NH}_{2}$ (Bachem) were used according to the manufacturer's instructions. 


\section{Bacterial strains, plasmids and media}

Eubacterium siraeaum DSM 15702 strain was grown under anaerobic conditions in Medium 110 with 15\% rumen fluid. Escherichia coli BL21 (DE3) were used in this study as host strain. Culture of different E. coli strains was done in Luria-Bertani (LB) medium. These media were supplemented, when necessary, with ampicillin $(50 \mu \mathrm{g} / \mathrm{ml})$, kanamycin $(25 \mu \mathrm{g} / \mathrm{ml})$ and IPTG (isopropyl $\beta$-D-thiogalactopyranoside) at $240 \mu \mathrm{g} / \mathrm{ml}$. The pDONR221 and pDEST-17 plasmids (Promega) were used as entry and expression vectors respectively.

\section{DNA manipulation and PCR}

Chromosomal DNA was isolated from E. siraeum DSM 15702 using the Wizard ${ }^{\circledR}$ Genomic DNA Purification kit (Promega). Preparation of plasmid DNA and separation of fragments by agarose gel electrophoresis were performed as described by Sambrook et al. [38]. To amplify the genes encoding for Siropins, we used gene-specific and universal primer pairs in a 1:4 ratio to generate the attachment binding sites (underlined) attb1 and attb2 in the final constructs. Based on the E. siraeum complete genomic sequence available in the NCBI Databank (ID: FP929044.1), we designed the specific oligonucleotide sequences F-SP1 5'GTACAAAAAAGCAGGCTTCAC AGGCATCAAAGCCGCAAGCC $3^{\prime}$ and R-SP1 $5^{\prime}$ CAAG AAAGCTGGGTCTCATATACCTGTATACACGCC ${ }^{\prime}$ for Siropin 1 gene amplification and both of F-SP2 5' $\underline{\text { GTAC }}$ A A A A A GCAGGCT TCAAAAGAAGA A T T T T ATCAGCA $3^{\prime}$ and R-SP2 5'CAAGAAAGCTGGGTCTT ATACGCCTGTATATATGCC3' were used to amplify the Siropin 2 gene. Furthermore, F-33 5'GGGGACAAG TTTGTACAAAAAAGCAGGCTTC $3^{\prime}$ and R-20 5'GGGG ACCACTTTGTACAAGAAAGCTGGGTC3' were used in this study as universal primers. Polymerase chain reactions were performed using Gene Amp ${ }^{\circledR}$ PCR System 9700 (Applied Biosystems). The amplification reaction contained Takara DNA polymerase amplification buffer, 20 pmol of each primer, $50 \mathrm{ng}$ of DNA template, and 5 units of Takara DNA polymerase (TaKaRa). PCR cycling parameters were: $94{ }^{\circ} \mathrm{C}$ for $5 \mathrm{~min}$, followed by 25 cycles of $94{ }^{\circ} \mathrm{C}$ for $30 \mathrm{~s}, 55^{\circ} \mathrm{C}$ for $60 \mathrm{~s}$, and $72{ }^{\circ} \mathrm{C}$ for $120 \mathrm{~s}$. PCR product was purified using QIAquick Gel Extraction Kit (Qiagen ${ }^{\circledR}$ ) by following the manufacturer's instructions. The purified fragments were used to be cloned into the Gateway plasmid pDONR-221 and therefore subcloned in the pDEST-17 expression vector by homologous recombination using the $\mathrm{BP}$ and $\mathrm{LR}$ clonase enzymes respectively (Invitrogen ${ }^{\circledR}$ ). After transformation in competent $E$. coli BL21 strain, numerous recombinant clones were obtained in case of each gene. Therefore sequence of two recombinant clones harboring the Siropins 1 or 2 genes under the control of the T7 promoter with six histidines at the $\mathrm{N}$-terminus of the protein, were confirmed.

\section{Siropins expression and purification}

Recombinant $E$. coli strains were grown as indicated above until the culture reached an $\mathrm{OD}_{600}$ of 0.6 , and the culture was induced for $3 \mathrm{~h}$ using IPTG $(240 \mu \mathrm{g} / \mathrm{ml})$ followed by harvesting of the cells by centrifugation $(8000 \mathrm{~g}$, for $15 \mathrm{~min}$ at $4{ }^{\circ} \mathrm{C}$ ). Pellets were resuspended in $20 \mathrm{mM}$ Tris- $\mathrm{HCl}$ buffer, pH 8.0 containing $500 \mathrm{mM} \mathrm{NaCl}$. The cell suspensions $(20 \mathrm{ml} /$ pellet from $1 \mathrm{~L}$ of culture) were incubated for $1 \mathrm{~h}$ on ice in the presence of $10 \mathrm{mM} \mathrm{MgCl}_{2}$ and $200 \mathrm{U}$ benzonase $\left(\right.$ Novagen ${ }^{\circledR}$ ). Cell disruption was done by sonication at $4{ }^{\circ} \mathrm{C}$ for $1 \mathrm{~min}$ (three cycles of $10 \mathrm{~s}$ pulses at amplitude of 40\%) using a Vibra-CellTM 72408 Sonicator and cell debris was removed by centrifugation $\left(16,000 \mathrm{~g}\right.$, for $30 \mathrm{~min}$ at $\left.4{ }^{\circ} \mathrm{C}\right)$. Purification was performed by affinity chromatography using a $1 \mathrm{ml}$ HiTrap chelating HP column (GE Healthcare) charged with $\mathrm{Ni}^{2+}$ ions on the ÄKTA Purifier FPLC system (Amersham Pharmacia Biotech) and equilibrated with $20 \mathrm{mM}$ Tris- $\mathrm{HCl} \mathrm{pH} 8.0$ buffer supplemented with $500 \mathrm{mM} \mathrm{NaCl}$. Proteins were eluted using linear imidazole gradient ranging from 0 to $500 \mathrm{mM}$. The fractions containing serpins activity were pooled and protein purification was achieved by size exclusion chromatography using Superdex S-200 10/300 GL column (GE Healthcare). Proteins elution was done through an isocratic gradient with a flow rate of $0.3 \mathrm{ml} /$ min in the same buffer.

\section{Protein analysis, amino acid sequence alignment and homology modeling}

Protein concentration was determined by measuring the UV absorption at $280 \mathrm{~nm}$ using a Nanodrop device (Thermos Fisher Scientific). The protein samples were separated in $12 \%$ SDS-PAGE according to the Laemmli method [39], and bands were visualized by Coomassie brilliant blue R-250 (Bio-Rad) staining. The estimated molecular mass of purified Siropins was confirmed by the size exclusion chromatography. Correspondence of purified proteins to Siropins was confirmed by mass spectrometry and western blotting approaches.

Purified Siropins were analyzed by SDS-PAGE and then electrotransferred to nitrocellulose membranes (HybondECL, Amersham Biosciences) which were blocked in phosphate-buffered saline solution containing $0.05 \%$ Tween $20(\mathrm{v} / \mathrm{v})$ and 5\% defatted milk powder (wt/vol) at $4{ }^{\circ} \mathrm{C}$ during $1 \mathrm{~h}$. Subsequently, blots were incubated with primary antibody (with 1/10,000 dilution of mouse antipolyHistidine monoclonal antibody, Sigma) at room temperature for $1 \mathrm{~h}$. Treated membranes were washed three times with the phosphate-buffered saline solution and incubated with goat anti-mouse HRP (Bio-Rad) during 
$1 \mathrm{~h}$. Blot signals were detected using chemiluminescent substrate and ChemiDoc ${ }^{\mathrm{TM}}$ MP System (Bio-Rad).

The multiple alignment of the Serpin amino-acid sequence was done using the program ClustalW [40] and the figure rendering was done using the ESPript sequence analysis server [41]. The 3D homology model of Siropin 1 and 2 was generated using the Geno3D server, and images were rendered by using VIEWERLITE ${ }^{\mathrm{TM}} 5.0$.

\section{Enzyme inhibition assays}

All reactions were assayed in $20 \mathrm{mM}$ tris- $\mathrm{HCl}, 500 \mathrm{mM}$ $\mathrm{NaCl}, \mathrm{pH} 8.0$ buffer. All substrates were suspended in DMSO and stored at $-80{ }^{\circ} \mathrm{C}$ and used in the final concentration of $200 \mu \mathrm{M}$ for MeOSuc-AAPV-pNA and $10 \mu \mathrm{M}$ for MCA-RPKPVE-Nval-WRK(Dnp)- $\mathrm{NH}_{2}$. Reaction mixture is composed of each serine protease with equimolar concentration of Siropin in the appropriate buffer and then incubated during $30 \mathrm{~min}$. Inhibition is measured by addition of the chromogenic or fluorogenic substrates in a final volume of $100 \mu \mathrm{l}$ in 96-well plates with clear or black bottom, respectively. Residual activity was determined during $20 \mathrm{~min}$ at $37^{\circ} \mathrm{C}$ using a plate reader (Synergy $^{\mathrm{TM}} 2$ Multi-Mode Microplate Reader, BioTek $^{\circledR}$ ) for pNA substrates (absorbance at $405 \mathrm{~nm}$ ) and (Dnp) $-\mathrm{NH}_{2}$ (excitation $360 \mathrm{~nm}$, emission $460 \mathrm{~nm}$ ). The final concentration of enzyme was $0.2,0.3$ and $1 \mu \mathrm{M}$ for HNE, PR3 and PPE, respectively. Concentration of $50 \mathrm{nM}$ was used for subtilisin (Sub), bovine pancreatic trypsin (BPT) and bovine pancreatic chymotrypsin (BPC).

\section{Stoichiometry of inhibition}

Stoichiometry of inhibition was determined by varying the amount of Siropins with a concentration of $200 \mathrm{nM}$ for HNE and $300 \mathrm{nM}$ for PR3. In fact, proteases and Siropins were gently mixed yielding to molar ratios of protease/inhibitor ranging from 0 to 10 during $5 \mathrm{~min}$ at $37{ }^{\circ} \mathrm{C}$. Therefore, substrate was then added and activity was assessed for $30 \mathrm{~min}$ by measuring absorbance at $405 \mathrm{nM}$. Fractional activity (velocity of the inhibited enzyme reaction/velocity of the non inhibited enzyme reaction) was subsequently calculated and plotted to the concentration ratio of the inhibitor to enzyme ([I0/E0]). The stoichiometry of inhibition was determined by linear regression as the $\mathrm{x}$-intercept.

\section{Determination of the P1-P1' site of siropins and mass spectrometry analysis}

The RCL cleavage site was determined by mixing Siropin $(40 \mu \mathrm{M})$ with HNE or PR3 in a total volume of $10 \mu \mathrm{l}$. Final enzyme/inhibitor ratio was 3 for HNE and 1 for PR3. After incubation for $5 \mathrm{~min}$ at $25{ }^{\circ} \mathrm{C}$, the reaction was stopped by addition of $20 \mu \mathrm{l}$ of boiling SDS-PAGE sample buffer followed by incubation for $5 \mathrm{~min}$ at $100{ }^{\circ} \mathrm{C}$.
Samples were then subjected to electrophoresis under reducing conditions according to the Laemmli method [39]. Subsequently, Protein bands of the Coomassiestained gel were excised and subjected to mass spectroscopy. The gel pieces were washed, reduced using DTT and alkylated with iodacetamide. 20-30 $\mu \mathrm{l}$ of $3 \mathrm{M}$ $\mathrm{HCl}$ was then added and the dehydrated gel pieces were microwaved for $10 \mathrm{~min}$ at $900 \mathrm{~W}$. The supernatant was removed and desalted directly on Oasis HLB Elution Plate (Waters). Samples were eluted in $50 \mu \mathrm{l}$, dried in a speed vacuum centrifuge and dissolved in $10 \mu \mathrm{l}$ of reconstitution buffer (96:4 water/acetonitrile and $0.1 \%$ formic acid) and analyzed by LC-MS/MS. For this analysis, peptides were separated using the nanoAcquity UPLC system (Waters) fitted with a trapping (nanoAcquity Symmetry $\mathrm{C}_{18}, 5 \mu \mathrm{m}, 180 \mu \mathrm{m} \times 20 \mathrm{~mm}$ ) and analytical column (nanoAcquity BEH C $18,1.7 \mu \mathrm{m}, 75 \mu \mathrm{m} \times 200 \mathrm{~mm}$ ) coupled directly to an linear trap quadropole (LTQ) OrbitrapVelos (Thermo Fisher Scientific) with a Proxeonnanospray source. The peptides were introduced into the mass spectrometer (OrbitrapVelos Pro, Thermo) and a spray of $2.2 \mathrm{kV}$ was applied. Peptides analysis was performed using MaxQuant Software (version 1.0.13.13). The data were searched against a species-specific (E. siraeum) Uniprot database with a list of common contaminants appended.

\section{Temperature, $\mathrm{pH}$ and stability profiles}

The effect of temperature on the serpin activity was determined by incubating of each purified Siropin for $30 \mathrm{~min}$ at various temperatures ranging from 4 to $90{ }^{\circ} \mathrm{C}$ and then the measurement of the residual inhibition was monitored. The Siropins $\mathrm{pH}$ profiles were obtained at different $\mathrm{pH}$ values between 2 and 10 (using $20 \mathrm{mM}$ Tris- $\mathrm{HCl}, 500 \mathrm{mM} \mathrm{NaCl}$ ). The stability as a function of temperature and $\mathrm{pH}$ was carried out by incubating each Siropin at different temperature and $\mathrm{pH}$ during different period and measuring residual activity.

\section{Kinetic characterization of siropins}

Kinetics of HNE and PR3 inhibition by Siropins were studied by the progress curve method [42, 43] under pseudo-first-order conditions, where the initial concentration of Siropin were varied from 1 to tenfold greater than that of proteases. Initial reaction mixture contains substrate at final concentration of $200 \mu \mathrm{M}$ and various amount of Siropins incubated at $37^{\circ} \mathrm{C}$ for $10 \mathrm{~min}$. Thereafter $10 \mu \mathrm{l}$ of HNE (200 nM) or PR3 (300 nM) were added to the mixture and the rate of the substrate hydrolysis was monitored at $405 \mathrm{~nm}$ for $20 \mathrm{~min}$. The progress curves were fitted by non linear regression and the pseudo first order association rate constant, $k_{o b s}$, was calculated using the Eq. $1[42,43]$. 


$$
P=\left(v_{0} / k_{o b s}\right) / 1-e^{-t \cdot k_{o b s}}
$$

where $P$ is the product concentration, $v_{0}$ is the substrate hydrolysis velocity and $\mathrm{t}$ is the reaction time. Determined $k_{o b s}$ were plotted as a function of Siropin concentration. The apparent second order associate constant $k_{a p p}^{\prime}$ was considered to be the slope of the fitted linear curve. Taking into account the competitive nature of inhibition by serpin, the second order association rates were then corrected using the Eq. $2[42,43]$.

$$
K_{a}=k_{\text {app }}^{\prime}\left(1+[S] / K_{m}\right)
$$

where $[S]$ is substrate concentration and $K_{m}$ is the Michaelis-Menten constant determined from the Lineweaver-Burk plot. $K_{m}$ values were $114 \mu \mathrm{M}$ for HNE and $270 \mu \mathrm{M}$ for PR3.

\section{Fecal protein extraction and inhibition analysis}

Fecal samples collected from 57BL/6 J (6-8 weeks old) treated with phosphate buffer and DSS dissolved in drinking water (3\%) during 7 days with free access to food and water. All procedures were performed according to the European Community Rules and approved by the Animal Care Committee (C2E-45 COMETHEA) with authorization number A78-322-6.

Feces were homogenized in cooled $20 \mathrm{mM}$ Tris- $\mathrm{HCl}$, $150 \mathrm{mM} \mathrm{NaCl}, \mathrm{pH}$. Cells were subsequently lyzed by sonication at $4{ }^{\circ} \mathrm{C}$ for $1 \mathrm{~min}$ ( 3 cycles of $10 \mathrm{~s}$ pulses at amplitude of 40\%) using a Vibra-CellTM 72408 Sonicator and cell debris was removed by centrifugation $(15,000 \mathrm{~g}$, for $30 \mathrm{~min}$ at $4{ }^{\circ} \mathrm{C}$ ). Recovered supernatants containing extracted proteins were then filtered $(0.45 \mu \mathrm{m})$ and used for monitoring the fecal protease activity.

Reactions were performed in $20 \mathrm{mM}$ Tris- $\mathrm{HCl}$, $150 \mathrm{mM} \mathrm{NaCl}, \mathrm{pH}$ 8. Inhibition of total fecal proteolytic activity was performed in $1 \mathrm{ml}$ reaction volume containing fecal proteins $(0.1 \mathrm{mg} / \mathrm{ml})$ with various amounts of Siropins and $100 \mu \mathrm{l}$ of casein $1 \%(\mathrm{w} / \mathrm{v})$. After incubation during $1 \mathrm{~h}$ at $37^{\circ} \mathrm{C}$, casein hydrolysis was stopped with $500 \mu \mathrm{l}$ of $20 \%(\mathrm{w} / \mathrm{v})$ trichloracetic acid (sigma). Precipitated proteins were removed by centrifugation $(15,000 \mathrm{~g}$, $15 \mathrm{~min}$ at $4{ }^{\circ} \mathrm{C}$ ) and the residual enzymatic activity was measured in the clear supernatant at $280 \mathrm{~nm}$.

The effect of Siropin on elastolytic activities were measured in $100 \mu \mathrm{l}$ reaction volume using MeOSucAAPV-pNA as substrate. Each fecal sample $(4 \mathrm{mg} / \mathrm{ml})$ was incubated with different amount of Siropin and then incubated for $30 \mathrm{~min}$ at $25{ }^{\circ} \mathrm{C}$. Subsequently, substrate $(150 \mu \mathrm{M})$ was added to the mixture and the absorbance change was monitored at $405 \mathrm{~nm}$ over $30 \mathrm{~min}$ at $37^{\circ} \mathrm{C}$ using a microplate reader (Synergy $^{\mathrm{TM}} 2$ Multi-Mode Microplate Reader, BioTek ${ }^{\circledR}$ ).

\section{Additional file}

Additional file 1: Figure S1. The predicted 3-dimensional structure of Siropin 1 and 2 showing the reactive center loop and the $\mathrm{N}$-termini highlighted in red.

\section{Authors' contributions}

HM performs experiments and participate to the analysis and the writing of the manuscript. NA participated in the biochemical experiments. VM participates to the sequence analysis and proteins purification and characterization. FS participates to sequence analysis. NP performs in silico studies. JM participates in the sequence analysis of Siropins and drafting the manuscript AG, contributed to the design of the work. EM participated in the design of the work and editing of the manuscript. MR participates in the design of the work, performing experiments and writing the manuscript. All authors read and approved the final manuscript.

\section{Author details}

${ }^{1}$ UMR 1319 Micalis, INRA, AgroParisTech, Université Paris-Saclay, 78350 Jouy-en-Josas, France. ${ }^{2}$ Laboratory of Molecular Biology of Eukaryotes, Center of Biotechnology of Sfax, University of Sfax, 3038 Sfax, Tunisia. 3 European Molecular Biology Laboratory, Grenoble Outstation, 71 Avenue des Martyrs, CS 90181, 38042 Cedex 9 Grenoble, France. ${ }^{4}$ INRA, Institut National de la Recherche Agronomique, US 1367 Metagenopolis, Jouy-en-Josas, France.

\section{Acknowledgements}

The authors would like to express their gratitude to A. SLIMI for his help with figure treatment and Anaxem platform for animal handling. HM, NA and AG were supported by the project CMCU-PHC Utique ( $n^{\circ} 14$ G0816)-Campus France ( $\left.n^{\circ} 30666 \mathrm{QM}\right)$. Part of the project relates to SerpinGuTarget ANR14-CE-16-0018. We would like to thank A.L. Abraham, A. Bolotin, V. Rossi and $\mathrm{N}$. Thielens for the discussion on microbial serpins. We are also grateful for S.D. Ehrlich and F. Haimet to allow this collaboration.

\section{Competing interests}

The authors declare that they have no competing interests.

\section{Availability of data and materials}

All data generated or analysed during this study are included in this published article.

\section{Ethics approval and consent to participate}

All animal assays were performed following the European Guidelines for the Care and Use of Laboratory Animals and approved by the Animal Care Committee (C2E-45 COMETHEA) with authorization number A78-322-6.

\section{Funding}

The research project is funded by the Agence Nationale de la Recherche (ANR, Contract number 14-CE16-0018) and supported by the project CMCU-PHC Utique ( $\left.n^{\circ} 14 \mathrm{G} 0816\right)$-Campus France ( $\left.{ }^{\circ} 30666 \mathrm{QM}\right)$ notably for the mobilities of $H M, N A, A G, M R$ and $E M$.

Received: 24 July 2016 Accepted: 8 November 2016 Published online: 29 November 2016

\section{References}

1. Gaci N, Dobrijevic D, Boudebbouze S, Moumen B, Maguin E, Rhimi M. Patented biotechnological applications of serpin: an update. Recent Pat DNA Gene Seq. 2013;7:137-43.

2. Irving JA, Steenbakkers PJ, Lesk AM, Op den Camp HJ, Pike RN, Whisstock JC. Serpins in prokaryotes. Mol Biol Evol. 2002;19:1881-90.

3. Bots M, Medema JP. Serpins in T cell immunity. J Leukoc Biol. 2008;84:1238-47

4. Rau JC, Beaulieu LM, Huntington JA, Church FC. Serpins in thrombosis, hemostasis and fibrinolysis. J Thromb Haemost. 2007;5:102-15. 
5. Gettins PG. Serpin structure, mechanism, and function. Chem Rev. 2002;102:4751-804.

6. Lucas A, Liu L, Dai E, Bot I, Viswanathan K, Munuswamy-Ramunujam G, Davids JA, Bartee MY, Richardson J, Christov A, Wang H, Macaulay C, Poznansky M, Zhong R, Miller L, Biessen E, Richardson M, Sullivan C, Moyer R, Hatton M, Lomas DA, McFadden G. The serpin saga; development of a new class of virus derived anti-inflammatory protein immunotherapeutics. Adv Exp Med Biol. 2009;666:132-56.

7. Khan MS, Singh P, Azhar A, Naseem A, Rashid Q, Kabir MA, Jairajpuri MA. Serpin inhibition mechanism: a delicate balance between native metastable state and polymerization. J Amino Acids. 2011;2011:606797-807.

8. Huntington JA, Read RJ, Carrell RW. Structure of a serpin-protease complex shows inhibition by deformation. Nature. 2000;407:923-6.

9. Kang S, Barak Y, Lamed R, Bayer EA, Morrison M. The functional repertoire of prokaryote cellulosomes includes the serpin superfamily of serine proteinase inhibitors. Mol Microbiol. 2006;60:1344-54.

10. Ksiazek M, Mizgalska D, Enghild JJ, Scavenius C, Thogersen IB, Potempa J. Miropin, a novel bacterial serpin from the periodontopathogen Tannerella forsythia, inhibits a broad range of proteases by using different peptide bonds within the reactive center loop. J Biol Chem. 2015;290:658-70.

11. Fulton KF, Buckle AM, Cabrita LD, Irving JA, Butcher RE, Smith I, Reeve S, Lesk AM, Bottomley SP, Rossjohn J, Whisstock JC. The high resolution crystal structure of a native thermostable serpin reveals the complex mechanism underpinning the stressed to relaxed transition. J Biol Chem. 2005;280:8435-42.

12. Irving JA, Cabrita LD, Rossjohn J, Pike RN, Bottomley SP, Whisstock JC. The 15 A crystal structure of a prokaryote serpin: controlling conformational change in a heated environment. Structure. 2003;11:387-97.

13. Zhang Q, Buckle AM, Law RH, Pearce MC, Cabrita LD, Lloyd GJ, Irving JA, Smith Al, Ruzyla K, Rossjohn J, Bottomley SP, Whisstock JC. The N terminus of the serpin, tengpin, functions to trap the metastable native state. EMBO Rep. 2007;8:658-63.

14. Ivanov D, Emonet C, Foata F, Affolter M, Delley M, Fisseha M, Blum-Sperisen S, Kochhar S, Arigoni F. A serpin from the gut bacterium Bifidobacterium longum inhibits eukaryotic elastase-like serine proteases. J Biol Chem. 2006;281:17246-52.

15. Motta JP, Bermúdez-Humarán LG, Deraison C, Martin L, Rolland C, Rousset P, Boue J, Dietrich G, Chapman K, Kharrat P, Vinel JP, Alric L, Masss E, Sallenave JM, Langella P, Vergnolle N. Food-grade bacteria expressing elafin protect against inflammation and restore colon homeostasis. Sci Transl Med. 2012;4:158.

16. Manichanh C, Rigottier-Gois L, Bonnaud E, Gloux K, Pelletier E, Frangeul L, Nalin R, Jarrin C, Chardon P, Marteau P, Roca J, Dore J. Reduced diversity of faecal microbiota in Crohn's disease revealed by a metagenomic approach. Gut. 2006;55:205-11.

17. Kamada N, Seo SU, Chen GY, Núñez G. Role of the gut microbiota in immunity and inflammatory disease. Nat Rev Immunol. 2013;13:321-35.

18. Turroni F, Foroni E, O'Connell Motherway M, Bottacini F, Giubellini V, Zomer A, Ferrarini A, Delledonne M, Zhang Z, van Sinderen D, Ventura M. Characterization of the serpin-encoding gene of Bifidobacterium breve 210B. Appl Environ Microbiol. 2010;76:3206-19.

19. Roberts TH, Hejgaard J, Saunders NF, Cavicchioli R, Curmi PM. Serpins in unicellular Eukarya, Archaea, and Bacteria: sequence analysis and evolution. J Mol Evol. 2004;59:437-47.

20. Silverman GA, Bird PI, Carrell RW, Church FC, Coughlin PB, Gettins PG, Irving JA, Lomas DA, Luke CJ, Moyer RW, Pemberton PA, RemoldO'Donnell E, Salvesen GS, Travis J, Whisstock JC. The serpins are an expanding superfamily of structurally similar but functionally diverse proteins. Evolution, mechanism of inhibition, novel functions, and a revised nomenclature. J Biol Chem. 2001;276:33293-6.

21. Hopkins PC, Carrell RW, Stone SR. Effects of mutations in the hinge region of serpins. Biochemistry. 1993;32:7650-7.

22. Tanaka S, Koga Y, Takano K, Kanaya S. Inhibition of chymotrypsin- and subtilisin-like serine proteases with Tk-serpin from hyperthermophilic archaeon Thermococcus kodakaraensis. Biochim Biophys Acta. 2011:1814:299-307.
23. Cabrita LD, Irving JA, Pearce MC, Whisstock JC, Bottomley SP. Aeropin from the extremophile Pyrobaculum aerophilum bypasses the serpin misfolding trap. J Biol Chem. 2007;282:26802-9.

24. Kang UB, Baek JH, Ryu SH, Kim J, Yu MH, Lee C. Kinetic mechanism of protease inhibition by alpha-1-antitrypsin. Biochem Biophys Res Commun. 2004;32:409-15.

25. Duranton J, Bieth JG. Inhibition of proteinase 3 by a-1-antitrypsin in vitro predicts very fast inhibition in vivo. Am J Respir Cell Mol Biol. 2003:29:57-61.

26. Shiga Y, Yamagata $H$, Tsukagoshi N, Udaka S. BbrPI, an extracellular proteinase inhibitor of Bacillus brevis, protects cells from the attack of exogenous proteinase. Biosci Biotechnol Biochem. 1995;59:2348-50.

27. Eggers CT, Murray IA, Delmar VA, Day AG, Craik CS. The periplasmic serine protease inhibitor ecotin protects bacteria against neutrophil elastase. Biochem J. 2004;379:107-18.

28. Vergnolle N. Protease inhibition as new therapeutic strategy for GI diseases. Gut. 2016;65(7):1215-24.

29. Schmid M, Fellermann K, Fritz P, Wiedow O, Stange EF, Wehkamp J. Attenuated induction of epithelial and leukocyte serine antiproteases elafin and secretory leukocyte protease inhibitor in Crohn's disease. J Leukoc Biol. 2007;81:907-15.

30. Bhattacharyya A, Mazumdar S, Leighton SM, Babu RC. A kunitz proteinase inhibitor from Archidendron ellipticum seeds: purification, characterization, and kinetic properties. Phytochemistry. 2006;67:232-41.

31. Jiang CJ, Hao ZY, Zeng R, Shen PH, Liii JF, Wuuu B. Characterization of a novel serine protease inhibitor gene from a marine metagenome. Mar Drugs. 2011;9:1487-501.

32. Yi D, Xu L, Yan R, Li X. Haemonchus contortus: cloning and characterization of serpin. Exp Parasitol. 2010;125:363-70.

33. Beatty K, Bieth J, Travis J. Kinetics of association of serine proteinases with native and oxidized alpha-1-proteinase inhibitor and alpha-1-antichymotrypsin. J Biol Chem. 1980;255:3931-4.

34. Zani ML, Nobar SM, Lacour SA, Lemoine S, Boudier C, Bieth JG, Moreau T. Kinetics of the inhibition of neutrophil proteinases by recombinant elafin and pre-elafin (trappin-2) expressed in Pichia pastoris. Eur J Biochem. 2004;271:2370-8.

35. Travis J, Salvesen GS. Human plasma proteinase inhibitors. Annu Rev Biochem. 1983;52:655-709.

36. Tooth D, Garsed K, Singh G, Marciani L, Lam C, Fordham I, Fields A, Banwait R, Lingaya M, Layfield R, Hastings M, Whorwell P, Spiller R. Characterisation of faecal protease activity in irritable bowel syndrome with diarrhoea: origin and effect of gut transit. Gut. 2014;63:753-60.

37. Annaházi A, Gecse K, Dabek M, Ait-Belgnaoui A, Rosztóczy A, Róka R, Molnár T, Theodorou V, Wittmann T, Bueno L, Eutamene H. Fecal proteases from diarrheic-IBS and ulcerative colitis patients exert opposite effect on visceral sensitivity in mice. Pain. 2009;144:209-17.

38. Sambrook J, Fritsh EF, Maniatis T. Molecular cloning: a laboratory manual. 2nd ed. Cold Spring Harbor: Cold Spring Harbor Laboratory Press; 1989.

39. Laemmli UK. Cleavage of structural proteins during the assembly of the head of bacteriophage T4. Nature. 1970;227:680-5.

40. Thompson JD, Higgins DG, Gibson TJ. CLUSTAL W: improving the sensitivity of progressive multiple sequence alignment through sequence weighting, position-specific gap penalties and weight matrix choice. Nucleic Acids Res. 1994;22:4673-80.

41. Gouet P, Courcelle E, Stuart DI, Métoz F. ESPript: analysis of multiple sequence alignments in PostScript. Bioinformatics. 1999;15:305-8.

42. Schechter NM, Plotnick MI. Measurement of the kinetic parameters mediating protease-serpin inhibition. Methods. 2004;32:159-68.

43. Morrison JF, Walsh CT. The behavior and significance of slow-binding enzyme inhibitors. Adv Enzymol Relat Areas Mol Biol. 1988;61:201-301. 